Volume: 12 Issue: 1 Year: 2015

\title{
Marx's distinction between socialism and communism
}

\author{
Taner Çam ${ }^{1}$ \\ Mustafa Kayaoğlu ${ }^{2}$
}

\begin{abstract}
Marx's distinction between socialism and communism is the subject of this study. Even though socialism and communism terms existed before Marx, they are generally remembered with Marx. From his perspective, socialism and communism was comprehensively handled and compared in the paper. Since it is essential to talk about it while discussing the distinction between socialism and communism, the dictatorship of the proletariat that is a political transition period is also explained in this study. Communism has two phases. The first or lower phase of communism is called as socialism that is the phase between capitalism and communism. The second or higher phase of communism is the perfect stage. There is no inequality or injustice in this stage. Communist society is classless society where products are delivered according to individuals needs. Implications were discussed in the work. Without three of the all sources, only Marx's own works were used during the examination of socialism and communism.
\end{abstract}

Keywords: Marx; socialism; communism, dictatorship of the proletariat.

\section{Introduction}

As it is known, these two terms; socialism and communism are the concepts existed before Marx. That is, Marx was not the creator of these concepts. In our contemporary society, Marx could be called as the most-respected authority and reference point to understand these concepts; however, the words; socialism and communism still have various meanings and applications. Therefore, in this work, Marx's distinction between socialism and communism will be explained.

According to Marx, communism comes after capitalism. To him the overthrow of all or any segment of capitalism is very important; however, it is not this termination that Marx is really concerned, for him, it is the beginning of the process towards communism. This overthrow will be the mark of gradual transition from capitalism to communism. When we read Marx and also other

\footnotetext{
${ }^{1}$ Ph.D., Sociologist, taner.cam@gmail.com

${ }^{2}$ Ph.D., Sociologist, kayaoglu97@yahoo.com
} 
Çam, T., \& Kayaoğlu, M. (2015). Marx’s distinction between socialism and communism. International Journal of Human Sciences, 12(1), 385-391. doi: 10.14687/ijhs.v12i1.3152

Marxist writers we can see that once political power has been won by the proletariat or working class, the old society cannot be turned into a basically different one in a single revolution.

As noted above, this would be the beginning and it requires a long period of time for the remnants of capitalism to lose their influence in that society. Thus, between the time that the workers overthrow capitalism and gain political control until the establishment of a perfect "classless society," there intervenes a period of social transformations which Marx has named "the dictatorship of the proletariat" (1850). It is a transition period, transition from the state to statelessness (Marx 1989).

Furthermore, to Marx, communism has two different phases. These are first or lower and second or higher phases. The first or lower phase is called as socialism. To mention the above distinction is very important because Marx uses this term for socialism in his works $(1875 ; 1989)$.

\section{Dictatorship of the Proletariat}

The dictatorship of the proletariat is a "political transition period." For the state of this period, it can be said that it is a "transition from the state to no state;" however, in this period state differs from the proper state. Even though in a capitalist society, state is needed by bourgeois, in the transition period, state is needed by proletariat. It is known that state is not a need in communist society (Gandy 1979; Marx 1989:55).

This dictatorship is not just the old capitalistic state in new groups. It is a new state having new rules and principles. The dictatorship of the proletariat occurs in the process of the breaking the bourgeois order. The difference between this state and the previous existing forms of the state is that: The dictatorships in former states have exploiting minorities over the exploited majorities; however, the dictatorship of the proletariat emerges as a dictatorship of the proletarian majority over the old oppressor bourgeois minority. Suppression is still a required tool during the transition from capitalism to communism. Here, roles of the groups change for suppression. This suppression is provided by the state; nevertheless, it is a transitory state. In this state, proletariats become ruling class (Marx 1989). The period between capitalism and communism is a revolutionary transformation period. "In order to achieve its emancipation, the proletariat must overthrow the bourgeoisie, conquer political power and establish its revolutionary dictatorship" (Marx 1989:72) because a political transition period is indispensable for the transition from capitalist society to communist society.

In The Class Struggles in France, 1848-50, Marx (1850) explains his thoughts about the dictatorship of the proletariat. He states that: 
Çam, T., \& Kayaoğlu, M. (2015). Marx’s distinction between socialism and communism. International Journal of Human Sciences, 12(1), 385-391. doi: 10.14687/ijhs.v12i1.3152

"...declaration of the permanence of the revolution, the class dictatorship of the proletariat as the necessary transit point to the abolition of class distinctions generally, to the abolition of all the relations of production on which they rest, to the abolition of all the social relations that correspond to these relations of production, to the revolutionizing of all the ideas that result from these social relations.."

and in the Critique of the Gotha Programme he also says that (Marx 1875):

"Between capitalist and communist society there lies the period of the revolutionary transformation of the one into the other. Corresponding to this is also a political transition period in which the state can be nothing but the revolutionary dictatorship of the proletariat."

These remarks clearly show that, by saying the dictatorship of the proletariat, Marx meant both a form of regime and government. In the form of government, the working class would govern and fulfill the tasks performing by the previous forms of state.

\section{Socialism}

According to Marx, socialism is the first or lower phase of communism (1875; 1989). Communism will come after a long revolutionary process. The society that would prevail, after the successful transition from bourgeois' institutions to the proletariat's institutions, still falls far short of strict communism.

This period purely is the first phase of communism called as socialism. However, the question whether socialism represents a stage in the transition to communism is something distinct from the dictatorship of the proletariat or not is still a problematic issue. In either case, it is certain that the dictatorship of the proletariat will remain during the period of socialism.

Marx's most important text on this subject is The Critique of the Gotha Programme (1875). Only in his Critique Marx distinguished the stages of communist society: the first or early phase emerged from capitalist society and the second or higher phase.

Socialism is the lower or first phase of communist society. The 'first phase' is the form of society which will immediately succeed capitalism. In this phase income will have to be calculated according to work done rather than according to need, in other words; "from each according to his ability, to each according to his needs". In the course of time the limits imposed by the capitalist 
Çam, T., \& Kayaoğlu, M. (2015). Marx’s distinction between socialism and communism. International Journal of Human Sciences, 12(1), 385-391. doi: 10.14687/ijhs.v12i1.3152

past will be transcended. Society will then enter what Marx called "the higher stage of communist society", “the classless society” (Marx 1875; Marx 1989:78- 80).

As it was mentioned above Marx made a distinction between these two "phases" in his Critique. However, the interesting part of The Critique of the Gotha Programme was that, the Critique was not published until 1891, couple of years after Marx's death. Its key place in the body of Marxist doctrine was not established until Lenin made it a central focus of his extremely influential The State and Revolution (1917), in which he stated that: "What is usually called socialism was termed by Marx was the "first" or lower phase of communist society'. So, it was Lenin, in The State and Revolution, who gave currency to a description of these two stages as 'socialism' and 'communism', not Marx (Lenin 1917; Marx 1989:78- 80).

It can be said that Marx did not make a distinctive separation between these concepts. However, if we know that the first or lower face of communism is socialism, it will help us to understand the difference between socialism and communism.

In this stage, the means of production change hands. They are not the private property of individuals anymore. Now, they are the property of whole society (Marx 1875; Marx 1989). In the early phase of communist society called as socialism, 'bourgeois right' is only abolished partly, "only in proportion to the economic transformation." While the means of production was admitted as the private property of individuals according to bourgeois right thought, they are converted into common property by socialism. Then bourgeois right disappears (Marx 1875; Marx 1989:78). Proletariat will be ruling class, they will use political supremacy, and they will "centralize all instruments of productions in the hands of state" (Marx 1989:63). This state will be governed by them.

In the first phase (socialism), communism will not be mature enough economically. In this stage, the effects of traditions and capitalism will be seen and traced (Marx 1989). In this stage, products will be delivered according to the amount of labor. In a society, each member of society performs an amount of work. With a certificate showing this amount that person takes a corresponding quantity of products (Marx 1875; Marx 1989).

\section{Communism}

According to Marx, equality and justice cannot be produced in the first phase of communism (socialism). In this stage (socialism) unjust and unequal differences are still seen in wealth; however, "exploitation of man by man" will not be seen. It will not be possible to take under control of the means of production by minority groups as it was seen in capitalism. 
Çam, T., \& Kayaoğlu, M. (2015). Marx’s distinction between socialism and communism. International Journal of Human Sciences, 12(1), 385-391. doi: 10.14687/ijhs.v12i1.3152

Exploitation will be impossible because means of production will not be private property in this stage (Marx 1875; Marx 1989:78-79).

To Marx, communism is the perfect stage. There is no injustice or inequity in this stage. This stage is called as higher phase of communist society by Marx. In this stage, products will be delivered according to each person's need instead of according to his/her amount of labor or ability as it was seen in socialism. Although, there needs to be a state in socialism, the state will not exist in communism because when there will be state there will not be freedom. However, in socialism state is needed for transition and suppression. It is needed to overthrow the bourgeois. It is needed to give the means of productions to whole society (Gandy 1979; Marx 1875; Marx 1989; Moore 1980).

The resistance of bourgeois will be broken in communist society. According to Marx, with the progress of time the classless society will appear. The individuals will be equal in terms of using the social means of production in this stage (Marx 1875; Marx 1989). The outstanding feature of this society in the eyes of Marx is that the rule of distribution will not be based on the usefulness of an individual to society anymore; nevertheless, it will be based on the fulfillment of needs, in other words; "from each according to his ability, to each according to his needs" (1875).

In defining communism, to quote Marx (1848:78);

"All property relations in the past have continually been subject to historical change consequent upon the change in historical conditions. The French Revolution, for example, abolished feudal property in favor of bourgeois property.The distinguishing feature of communism is not the abolition of property generally, but the abolition of bourgeois property. But modern bourgeois private property is the final and most complete expression of the system of producing and appropriating products that is based on class antagonisms, on the exploitation of the many by the few.In this sense the general meaning of communism could be summed up in a single sentence: Abolition of private property."

In the Economic and Philosophical Manuscripts of 1844 (Third Manuscript) Marx (1844) wrote;

"Communism as the positive transcendence of private property as human self-estrangement, and therefore as the real appropriation of the buman essence by and for man; communism therefore as the complete return of man to himself as a social (i.e., human) being - a return accomplished consciously and embracing the entire wealth of previous development." 
Çam, T., \& Kayaoğlu, M. (2015). Marx’s distinction between socialism and communism. International Journal of Human Sciences, 12(1), 385-391. doi: 10.14687/ijhs.v12i1.3152

If we look at this concept from a sociological perspective we will see that Marx and Engels gave communism a more sociological meaning by specifying the abolition of classes and of the division of labor as pre-conditions for a communist society; thus, in the German Ideology (vol. 1, section I), Marx (1845) discussed that to attain the communist society it would be needed for people to

“...re-establish their control over these material powers and abolish the division of labor. This is not possible without a community. . . The illusory community in which, up to the present, individuals have combined, always acquired an independent existence apart from them, and since it was a union of one class against another it represented for the dominated class not only a completely illusory community but also a new shackle. In a genuine community individuals gain their freedom in and through their association."

If we think about the characteristic of this society, which would be a society without private property, class divisions, or an extensive division of labor, it becomes more clear why Marx and Engels referred to early tribal societies in this sense, as primitive communism.

In his work Capital, Marx emphasized the economic character of the future communist society, as a "society of associated producers", arguing in Capital III (chapter 48, section 3) that freedom in the economic sphere could consist; “...in socialized man, the associated producers, rationally regulating their interchange with Nature, bringing it under their common control, instead of being ruled by it as by the blind forces of Nature" (1894).

To Marx, the state as the instrument and symbol of class exploitation will vanish with classes and their exploitation. It is not going to be abolished; it simply would "wither away," since it is no longer of any use (Marx 1875; Marx 1989:55).

For Marx (1875), the classless society - communism - will show forth man's true dignity. People will be completely free and developed by means of the labor. Men will no longer serve as mere commodities whose labor is bought and sold in the industrial market for the sake of profit (Marx 1849). Men become the primary concern of the new society. Then, such a society becomes "an association in which the free development of each is the condition for the free development of all” (Marx 1848).

\section{Conclusion}

Consequently, we can say that socialism is an indispensable stage between capitalism and communism. Socialism stage is a transition stage for transition to the perfect stage (communism). 
Çam, T., \& Kayaoğlu, M. (2015). Marx’s distinction between socialism and communism. International Journal of Human Sciences, 12(1), 385-391. doi: 10.14687/ijhs.v12i1.3152

Even though capitalism will not be traced in communism it will be traced in socialism. The resistance of the capitalist will be completely broken in communism. In socialism, inequality of distribution will still exist. It will continue by reaching communism. In socialism, state is needed by the proletariat; however, it is not needed in communism. In communism, products will be delivered according to people's needs instead of their ability. In communism, society will get rid of from traditions and traces of capitalism completely. Besides, communist society is classless society. Moreover, there will be freedom in communist society because there will not be state in communist society.

\section{References}

Gandy, Daniel R. 1979. Marx and History. Austin \& London: University of Texas Press.

Lenin, Vladimir. I. 1917. The State and Revolution. Retrieved March 8, 2008 (http://www.marxists.org/archive/lenin/works).

Marx, Karl. 1844. Economic and Philosophic Manuscripts. Retrieved March 8, 2008 (http://www.marxists.org/archive/marx/works).

Marx, Karl. 1845. The German Ideology. Retrieved March 8, 2008 (http://www.marxists.org/archive/marx/works).

Marx, Karl. 1848. The Communist Manifesto. Retrieved March 8, 2008 (http://www.marxists.org/archive/marx/works).

Marx, Karl. 1850. The Class Struggle in France, 1848 to 1850. Retrieved March 8, 2008 (http://www.marxists.org/archive/marx/works).

Marx, Karl. 1875. Critique of the Gotha Programme. Retrieved March 8, 2008 (http://www.marxists.org/archive/marx/works).

Marx, Karl. 1894. Capital, Volume III. Retrieved March 8, 2008 (http://www.marxists.org/archive/marx/works).

Marx, Karl. 1989. Critique of the Gotha Programme by Karl Marx with the Appendices by Marx, Engels and Lenin. New York: International Publisher Co., Inc.

Moore, Stanley. 1980. Marx on the Choice between Socialism and Communism. Cambridge, Massachusetts and London: Harvard University Press. 